\title{
Rock Mass Behavior of Large-scale Cavern during Excavation and Trend of Underground Space Use
}

by Satoshi HIBINO ${ }^{\mathrm{a}}$

a. Vice-President, Central Research Institute of Electric Power Industry, Abiko-shi 270-1194, Japan ; Visiting Professor, Tokyo Institute of Technology

Measurements of rock mass around large-scale caverns during excavation have revealed the typical behavior of jointed rock mass ; 1) deformation of rock mass consists of discontinuous displacement and continuous displacement, 2) ratio of these two displacements differs by kinds of rock and others.

KEY WORDS : Cavern, Measurement, Rock Test, Joint, Anisotropy, Lining Stress

\section{1.は じめに}

空洞の規模が小さい場合には空洞が安定している岩盤でも，大 きな空洞を掘削すると崩壊することがある。その原因としては, 岩盤に存在する節理など不連続面の影響などが考えられる。地下 発電所空洞 (断面積約 $1,000 \mathrm{~m}^{2}$ ) 掘削時の各種計測結果から判断寸 ると, 通常のトンネル (断面積 $100 \sim 200 \mathrm{~m}^{2}$ ) に比べ, これら不 連続面のために岩盤挙動が異なってくるように感じられる。異な るというよりは岩盤挙動の特徵をより典型的に示すと考えられ る。つまり,「空洞の安定性に対する不連続面の影響度合いは, 空 洞のスケール (規模) が大きくなるとより顕著になる」ものと判断 される。

ここで扱う大規模空洞は揚水式地下発電所の空洞である。高さ $40 \sim 60 \mathrm{~m}$, 幅 $20 \sim 30 \mathrm{~m}$, 奥行き $50 \sim 170 \mathrm{~m}$ (断面約 $1,000 \mathrm{~m}^{2}$, 容積約 $4 \sim 20$ 万 $\mathrm{m}^{3}$ ) の規模である ( 図 1)。新幹線トンネル (直径

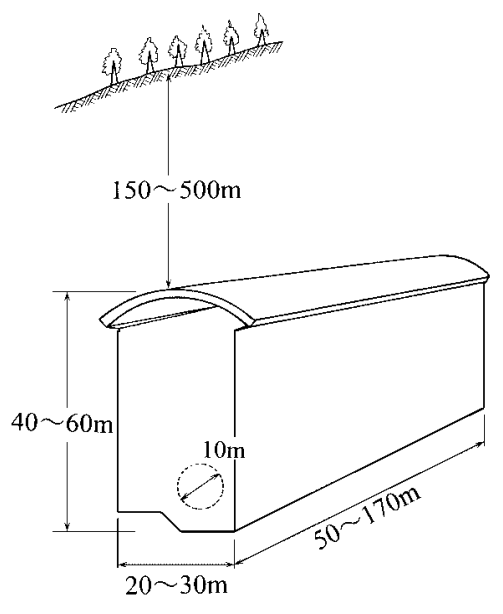

図 1 地下発電所空洞の規模

* 2001 年 1 月 22 日受付 2 月 13 日受理

1. 正会員 工博 (財) 電力中央研究所理事 東京工業大学客員教授 [ 著者連絡先 ] FAX 0471-82-9417(電中研)

キーワード：空洞，計測，岩盤試験，節理，異方性，ライニング応力，
約 $10 \mathrm{~m}$ ) や第二東名・名神高速道路トンネル (断面約 $\left.200 \mathrm{~m}^{2}\right)$ に 比べると空洞規模のスケールが一桁ほど大きい。

そこで本論文においては，岩盤のスケールと節理の影響を中心 にして, 岩盤構造物の設計で基本となる (1) 材料としての岩盤力 学特性の二, 三の問題点, (2) 外力としての地圧分布の特徵を述 ベ, ついで (3) 大規模空洞掘削時の岩盤挙動における節理等の影 響について触れ，最後に(4) 今後の地下空間利用について述べる。

\section{2. 材料としての岩盤の力学特性}

\section{$2 \cdot 1$ 岩盤試験のスケールとカ学特性値との関係}

岩盤の変形特性を求めるのに平板載荷試験が行われる。載荷板 の形状は直径 $30 \mathrm{~cm}$ の円盤の場合が多く, 場合によっては $60 \mathrm{~cm}$ の円盤あるいは $100 \mathrm{~cm}$ の角盤などが用いられる。断面積で見れば $0.07 \sim 1.0 \mathrm{~m}^{2}$ 程度である。一方岩盤構造物はダムであれば, その 接地面積は数千 $\mathrm{m}^{2}$ などとスケールが違う。このようにスケール が違うと, 岩盤の弾性係数も異なってくることが考えられる。し かし，このスケールの違いによる影響はあまり研究がされていな い。

岩盤試験の載荷面積 $(A)$ が異なると得られる弾性係数の值が 違ってくる例を図 2 に示寸 (Hibino and Kamijo, 1998)。この図は同 一地点 (花崗閃緑岩の岩盤) での平板載荷試験 ( 載荷板は $30 \mathrm{~cm}$ の 円盤 $A: 0.07 \mathrm{~m}^{2}$, $1 \mathrm{~m}$ 角板 $\left.A: 1.0 \mathrm{~m}^{2}\right)$, 岩盤三軸試験 $\left(A: 1.0 \mathrm{~m}^{2}\right)$, 水室試験 $\left(A: 56 \mathrm{~m}^{2}\right)$ で得られた弾性係数の值を示している。この 例では載荷する面積が大きくなるほど弾性係数の值が大きくなる 傾向が見られる。

つぎに黒部第四ダム ( 岩盤は花崗岩 ) で検討したマクロな岩盤 の弾性係数について述べる。同ダム地点においては各種の計測が 行われた。そのうち標高 $1,340 \mathrm{~m}$ の横坑内に設置された岩盤変位 計 ( 計測スパン: 29〜90 m) で, 貯水池の水面変動による岩盤変 形を計測して, マクロな岩盤の弾性係数として $100 \times 10^{3} \mathrm{kgf} / \mathrm{cm}^{2}$ が求められた。この值は同じ標高近傍の横坑内での平板載荷試験 (載荷板直径 $30 \mathrm{~cm}$ ) で得られた值 $\left(24 \sim 30 \times 10^{3} \mathrm{fkg} / \mathrm{cm}^{2}\right)$ の 2 4 倍であった (Hibino and Kamijo, 1998)。

このようにみてくると, 花崗岩系の岩盤などにおいては, 
Modulus of deformation $E\left(10^{3} \mathrm{kgf} / \mathrm{cm}^{2}\right)$

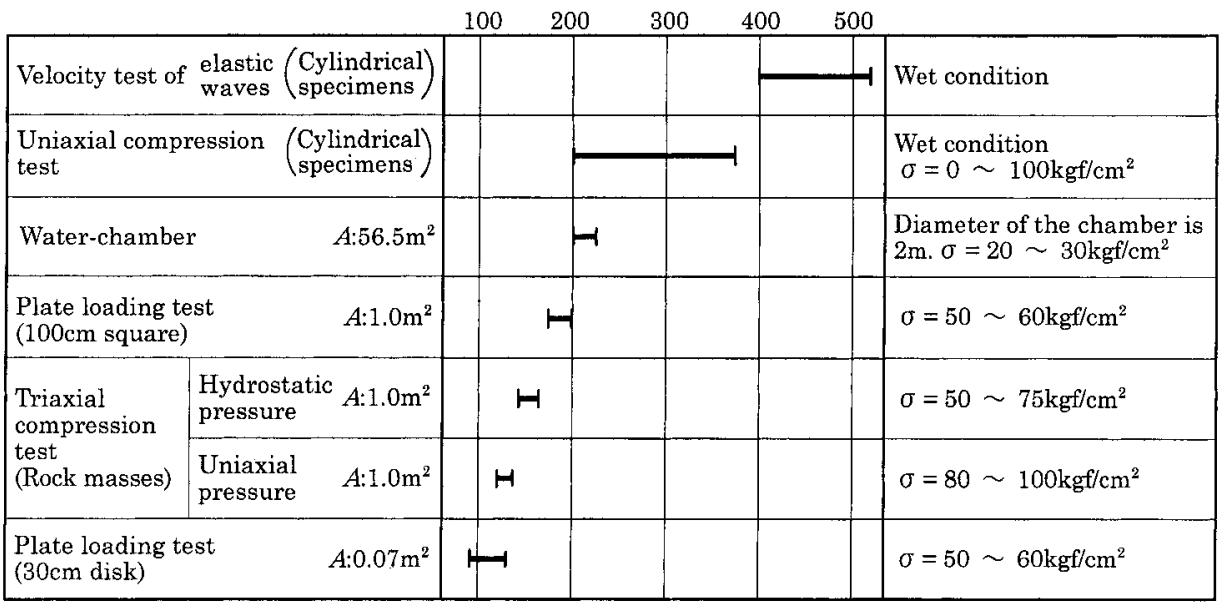

図 2 岩盤試験の種類と得られた弾性係数との関係 (花崗閃緑岩)

(1)平板載荷試験結果は弾性係数を過小評価している。

と考えられる。通常の設計では弾性係数が小さいと変形が大きく なり，一般には安全側となるが，対象とする岩盤構造物と岩盤試 験との相対関係を考慮して，岩盤試験結果を評価することが必要 である。

上記のことは岩盤の強度評価に関しても再検討してみる必要が あると考えられる。岩盤剪断試験では，供試体の寸法は通常は 60 $\mathrm{cm} \times 60 \mathrm{~cm} \times 40 \mathrm{~cm}$ 程度で, 平板載荷試験と同様試験規模が小さい。 大型な岩盤剪断試験は試験そのものが実施困難であり，マクロな 岩盤強度と通常の岩盤剪断試験による強度の比較をした例はほと んど見かけない。岩盤崩壊や岩盤滑りなどの実例から推定するの も一つの方法と考えられ, 今後さらに研究を進める必要がある。

\section{$2 \cdot 2$ 巨視的な岩盤の異方性（節理の卓越度による異方性）}

岩盤の異方性は大別すれば，構造的に三種類あると考えられる ( 表 1)。つまりミクロな構造によるものとして (1) リフト面グレン 面などに起因するもの，マクロな構造によるものとして（2）層理 面や片理面などに起因するものと, (3) 岩盤全体の広い範囲に分布 する節理などが統計的にみると卓越度を有することによるものの 3つである。ここでは (3)について述べる。

節理が発達しやすい花崗岩系岩盤での空洞掘削事例を表 2 に示 す (Hibino and Motojima, 1999)。空洞建設に際しては事前に掘削解 析による岩盤挙動の予測を行い (林・日比野, 1968), ついでその 結果と掘削時の計測結果と比較検討し，施工の安全をはかる情報 化施工が行われる。サイト 6 (1975) の地点においては当初岩盤を 等方性としていたが，岩盤変形の予測值と掘削時の計測結果の差

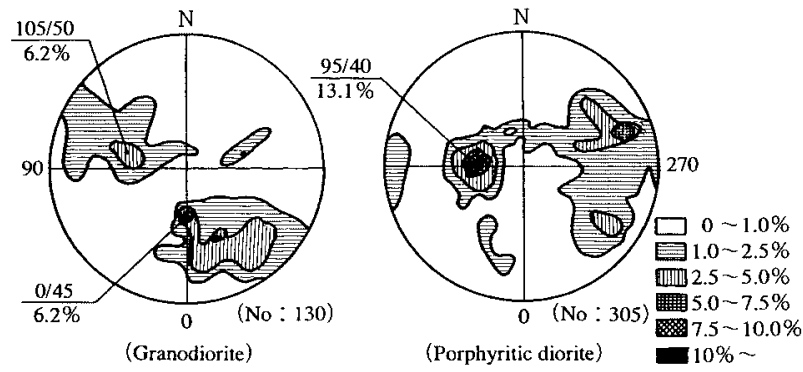

図 3 節理密度分布と卓越度, ウルフネット (堀ほか, 1977)

が大きく, 岩盤挙動の解釈ができなかった。そこで節理が発達し ていることによる異方性を導入し，それによって初めて岩盤の挙 動が理解できた（日比野・林ほか，1980)。岩盤節理の卓越度は通 常図 3 に示寸ように，節理をステレオ投影して求める。表 2 には 節理の卓越度による異方性考慮の必要性の有無を備考欄に示し た。これらの結果から判断すると，

(2)節理の卓越度が約 $10 \%$ 以上の岩盤では, 異方性を考慮する必 要がある。

と考えられる。

つぎに, 図 4 には表 2 のサイト 8 とサイト 14 での空洞掘削終了 時での岩盤変形量の違いを示寸。両地点の弾性係数の最大值はほ ぼ同じで $15 \sim 20$ 万 $\mathrm{kgf} / \mathrm{cm}^{2}$ (表 4 参照) である。しかし, 卓越節 理の方向と空洞の側壁 (地圧解放自由面) の方向とのなす角 $\theta_{\mathrm{j}}$ が 2 つのサイトで, $3^{\circ}$ と $63^{\circ}$ と大きく異なっている。 $\theta_{\mathrm{j}}$ が小さいほど節

表 1 岩盤の異方性の分類

\begin{tabular}{lllcl}
\hline & \multicolumn{2}{c}{ Kind of discontinuity } & Size & Measuring method \\
\hline Micro-structure & Rift/grain/hardway plane (micro crack) & $\mu \mathbf{m} \sim \mathbf{m m}$ & Vp velocity test \\
\hline \multirow{4}{*}{ Macro-structure } & $\begin{array}{l}\text { Joint plane (crack) } \\
\text { Bedding plane (grain sorting) } \\
\text { Schistosity (crack) }\end{array}$ & $\mathbf{c m \sim m}$ & Laboratory test \\
& $\begin{array}{l}\text { Rock mass test } \\
\text { Joint set (crack) }\end{array}$ & $\mathbf{m} \sim \mathbf{k m}$ & Statistic method \\
\hline
\end{tabular}

表 2 花崗岩系岩盤での大空洞掘削事例と節理卓越度

\begin{tabular}{ccclcl}
\hline No. & Site & & Kind of rock mass & $\begin{array}{l}\text { Predominance } \\
\text { of joint set }\end{array}$ & Remarks \\
\hline 5 & Nabara & $(1974)$ & Granite & $2.8 \sim 7.5$ joint/m & Isotropic \\
6 & Shintakase & $(1975)$ & Granodiorite, diorite & $12 \%, 7 \%$ & Anisotropic \\
8 & Okuyahagi & $(1978)$ & Granite & $11 \%, 9 \%$ & Anisotropic \\
11 & Arimine & $(1979)$ & Granite & $10 \%, 7.9 \%$ & Anisotropic \\
14 & Matano & $(1981)$ & Granite, porphyrite & $9 \%, 9 \%$ & Anisotropic \\
15 & Tenzan & $(1982)$ & Granodiorite & 0.09 joint/m & Isotropic \\
\hline
\end{tabular}



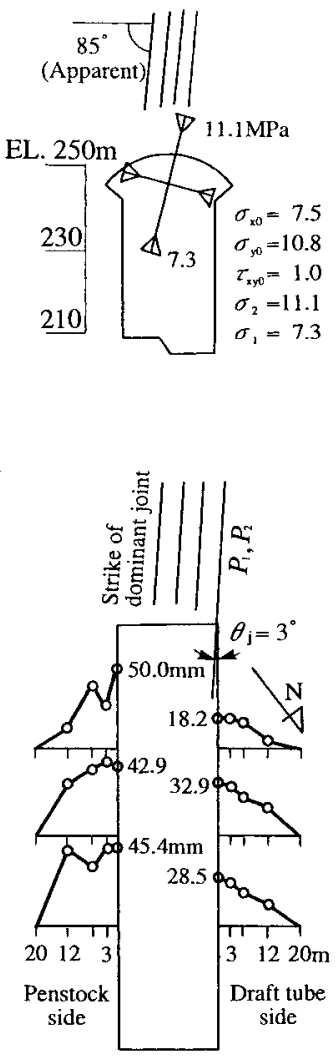

(EL. $232.25 \mathrm{~m}$ )

(a) Site No. 8

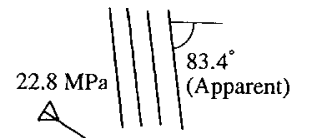

EL. $190 \mathrm{~m} \gg \sigma_{\mathrm{x} 0}=18.5$
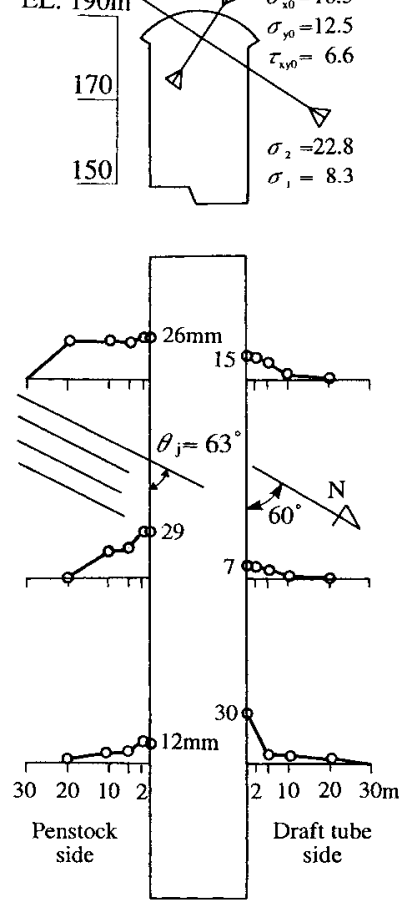

(EL. 170m)

(b) Site No.14
図 4 角度 $\theta_{\mathrm{j}}$ の違いと空洞側壁岩盤の水平方向変位との関係

理による異方性の発現度は大きくなる配置となる。したがって, 最大地圧の大きさはサイト 8 ではサイト 14 に比べ, 約半分である にもかかわらず, 岩盤変形量は逆に約 2 倍となっている。「卓越節 理の方向と岩盤構造物の配置により, 安定性は異なってくる」こ とを示していると考えられる。

卓越度が $10 \%$ の場合と $20 \%$ とでは異方性の度合いはどう違う か, また節理面の力学的特性と岩盤の異方性度の関係は? など, 今後解明を要する項目である。

\section{3. 外カとしての地圧特性}

（1）地圧の水平成分と鉛直成分の比率

地下発電所の空洞掘削に際しては地圧計測を実施する。表 3 に その結果を示す (Kanagawa, Hibino et al., 1986)。実施地点は図 7 に 示寸ように日本全国にわたっている。水平成分と鉛直成分の比率 の平均值は 1.36 で水平方向の方が鉛直方向より大きいことが分か る。つまり，

(3)日本では地圧の水平成分が鉛直成分よりも卓越する。

この原因としてはプレートテクトニックスによる影響や地球の 重力による影響などが考えられている。地圧の鉛直成分は, 多く の場合被り相当圧 (被り厚さと単位体積重量の積) に近い值が計 測されている。測定位置や地形の影響などにより当然比率も違っ てくるが, 計測地点は図 7 に示すように日本全国にわたっており, 日本列島を一つの供試体と考えるならば, 地圧の第一近似值とし て, 鉛直成分は被り相当圧, 水平成分はその 1.4 倍程度の值を用 いることが考えられる。

(2) 岩盤の堅さと地圧の関係

図 5 には青函トンネルの作業坑で計測した地圧を示す（金川・

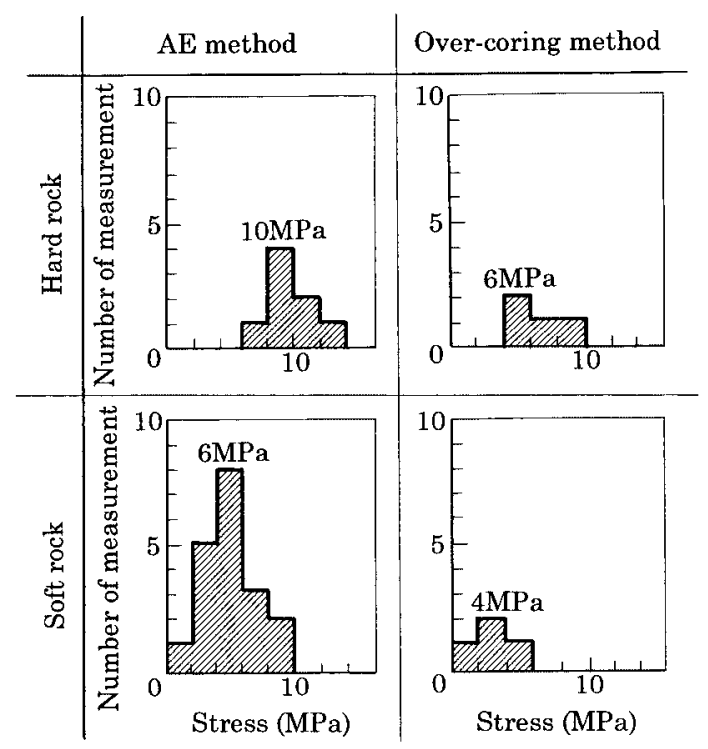

図 5 岩盤の硬軟と初期地圧の大きさとの関係 (金川ほか, 1977)

表 3 オーバーコアリング法による初期地圧測定結果 (金川ほか，1986)

\begin{tabular}{|c|c|c|c|c|c|c|c|c|c|c|c|c|c|c|c|}
\hline \multirow[b]{3}{*}{$\begin{array}{l}\text { Kind of } \\
\text { rock }\end{array}$} & \multirow[b]{3}{*}{$\begin{array}{c}\text { Density } \\
\left(t / m^{3}\right)\end{array}$} & \multirow{3}{*}{$\begin{array}{c}\text { Young's } \\
\text { modulus } \\
\text { (GPa) }\end{array}$} & \multirow[b]{3}{*}{$\begin{array}{l}\text { Elevation } \\
\text { (m) }\end{array}$} & \multirow[b]{3}{*}{$\begin{array}{c}\text { Depth } \\
\text { (m) }\end{array}$} & \multicolumn{6}{|c|}{ Principal stress } & \multirow{2}{*}{\multicolumn{2}{|c|}{$\begin{array}{l}\text { Horizontal } \\
\text { stress }\end{array}$}} & \multirow[b]{3}{*}{$\begin{array}{c}\text { Direction of } \\
\sigma_{\mathrm{H}_{\max }}\end{array}$} & \multirow{3}{*}{ 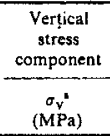 } & \multirow[b]{3}{*}{$\frac{\sigma_{H \max }}{\sigma_{y}}$} \\
\hline & & & & & \multicolumn{2}{|c|}{$\sigma_{1}$} & \multicolumn{2}{|r|}{$\sigma_{2}$} & \multicolumn{2}{|c|}{$\sigma_{3}$} & & & & & \\
\hline & & & & & $\begin{array}{c}\text { Magnitude' } \\
(\mathrm{MPa})\end{array}$ & $\begin{array}{c}\text { Orientation } \\
\text { (degree) }\end{array}$ & $\begin{array}{c}\text { Magnitude" } \\
\text { (MPa) }\end{array}$ & $\begin{array}{c}\text { Orientation } \\
\text { (degree) }\end{array}$ & $\begin{array}{c}\text { Magnitude } \\
(\mathrm{MPa})\end{array}$ & $\begin{array}{l}\text { Orientation" } \\
\text { (degree) }\end{array}$ & $\begin{array}{c}\sigma_{\mathrm{Hmax}} \\
(\mathrm{MPa})\end{array}$ & $\begin{array}{l}\sigma_{\mathrm{Hmin}}{ }^{\prime \prime} \\
(\mathrm{MPa})\end{array}$ & & & \\
\hline Granite & 2.5 & 18 & 1054 & 250 & -10.8 & $260 / 10$ & -6.4 & $145 / 70$ & 0 & $355 / 20$ & -10.6 & -0.6 & $\mathrm{~N} 82^{\circ} \mathrm{E}$ & -6.0 & 1.77 \\
\hline Shale & 2.6 & 8 & 386 & 214 & - & - & - & - & - & - & -9.0 & -4.6 & N66" E & -7.3 & 1.24 \\
\hline Granite & 2.5 & 20 & 320 & 280 & -9.6 & $269 / 64$ & -7.5 & $73 / 25$ & -4.9 & $166 / 6$ & -7.9 & -4.9 & $\mathrm{~N} 77^{\circ} \mathrm{E}$ & -9.2 & 0.86 \\
\hline Black schist & 2.6 & 10 & 580 & 270 & -11.1 & $164 / 38$ & -5.4 & $38 / 37$ & -3.7 & $282 / 30$ & -8.7 & -4.4 & N9 ${ }^{\circ} \mathrm{W}$ & -7.2 & 1.22 \\
\hline Granite & 2.5 & 24 & 185 & 370 & -23.4 & $165 / 29$ & -13.2 & $56 / 29$ & -7.2 & $282 / 46$ & -20.2 & $-11 . I$ & $\mathrm{~N} 57^{\circ} \mathrm{W}$ & -12.5 & 1.61 \\
\hline Mudstone & 1.7 & 0.8 & -40 & 70 & -1.24 & $2 / 46$ & -1.08 & $115 / 20$ & -1.07 & $221 / 37$ & -1.16 & -1.09 & $N 1^{\circ} E$ & -1.17 & 0.99 \\
\hline Green schist & 2.5 & 5 & $s$ & 30 & -0.89 & $117 / 41$ & -0.66 & $349 / 35$ & -0.46 & $235 / 29$ & -0.77 & -0.53 & $\mathrm{~N} 48^{\circ} \mathrm{W}$ & -0.71 & 1.10 \\
\hline Rhyolite & 2.5 & 12 & 260 & 165 & -4.2 & $297 / 65$ & -3.3 & $194 / 63$ & -2.5 & $64 / 38$ & -4.0 & -3.0 & $\mathrm{~N} 53^{\circ} \mathrm{W}$ & -2.9 & 1.37 \\
\hline Granite & 2.5 & 30 & 130 & 510 & -15.8 & $232 / 13$ & -11.1 & $16 / 74$ & -6.3 & $140 / 9$ & -15.5 & -5.4 & $\mathbf{N} S 1^{\circ} \mathbf{E}$ & -11.2 & 1.39 \\
\hline Schalstein & 2.5 & 7 & 140 & 210 & -6.2 & $223 / 8$ & -4.8 & $128 / 34$ & -4.7 & $324 / 55$ & -6.2 & -4.8 & $\mathrm{~N}^{4} 4^{\circ} \mathrm{E}$ & -4.8 & 1.29 \\
\hline Siliceous & & & & & & & & & & & & & & & \\
\hline sandstone & $\begin{array}{l}2.5 \\
2.5\end{array}$ & $\begin{array}{l}26 \\
27\end{array}$ & $\begin{array}{l}540 \\
540\end{array}$ & $\begin{array}{l}420 \\
395\end{array}$ & $\begin{array}{l}-15.7 \\
-12.1\end{array}$ & $\begin{array}{l}263 / 25 \\
313 / 25\end{array}$ & $\begin{array}{r}-10.6 \\
-8.5\end{array}$ & $\begin{array}{r}21 / 45 \\
109 / 63\end{array}$ & $\begin{array}{l}-7.8 \\
-7.6\end{array}$ & $\begin{array}{l}155 / 34 \\
218 / 10\end{array}$ & $\begin{array}{l}-14.7 \\
-11.4\end{array}$ & $\begin{array}{l}-8.8 \\
-7.6\end{array}$ & $\begin{array}{l}N 78^{\circ} \mathrm{E} \\
N 48^{\circ} \mathrm{W}\end{array}$ & $\begin{array}{r}-10.6 \\
-9.1\end{array}$ & $\begin{array}{l}1.39 \\
1.24\end{array}$ \\
\hline $\begin{array}{l}\text { Breccia } \\
\text { Conglomerate }\end{array}$ & 2.5 & 14 & 601 & 270 & -8.2 & $196 / 10$ & -5.5 & $310 / 66$ & -4.9 & $102 / 22$ & -8.1 & -5.0 & N1 $16^{\circ} \mathbf{E}$ & -5.5 & 1.48 \\
\hline Conglomerate & 2.5 & 2.6 & -16 & 22 & -1.06 & $242 / 28$ & -0.72 & $151 / 3$ & -0.41 & $55 / 62$ & -0.92 & -0.71 & $\mathrm{~N} 65^{\circ} \mathrm{E}$ & -0.55 & 1.68 \\
\hline Quartz diorite & 2.5 & - & 550 & 15 & - & - & - & - & $\rightarrow$ & - & -7.4 & -2.6 & NY ${ }^{\circ} \mathrm{E}$ & -2.8 & 2.62 \\
\hline Rhyolite & 2.6 & 16 & 460 & 335 & -9.0 & $280 / 6$ & -6.2 & $15 / 37$ & -4.6 & $183 / 52$ & -8.9 & -5.6 & $\mathrm{~N} 81^{\circ} \mathrm{W}$ & -5.2 & 1.72 \\
\hline Mudstone & 2.0 & 1.2 & -20 & 30 & - & - & - & - & - & - & -0.49 & -0.45 & $\mathrm{~N} 35^{\circ} \mathrm{W}$ & -0.55 & 0.89 \\
\hline Granite & 2.5 & 12 & -47 & 71 & -5.5 & $85 / 7$ & -4.6 & $352 / 27$ & -4.1 & $189 / 62$ & -5.5 & -4.5 & $\mathrm{~N} B 7^{\circ} \mathrm{E}$ & -4.2 & 1.30 \\
\hline Rhyolite & 2.6 & 10 & 663 & 192 & -5.1 & $168 / 71$ & -4.3 & $347 / 20$ & -1.7 & $77 / 0$ & -4.4 & -1.7 & N1 $3^{\circ} \mathrm{W}$ & -5.0 & 0.88 \\
\hline Tuff breccia & 2.6 & 7 & 664 & 241 & -5.0 & $217 / 54$ & -3.7 & $31 / 36$ & -2.9 & $124 / 2$ & -4.1 & -2.9 & $\mathrm{~N} 35^{\circ} \mathrm{E}$ & -4.6 & 0.89 \\
\hline Porphyrite & 2.5 & 20 & 358 & 285 & -10.4 & $253 / 31$ & -7.0 & $163 / 1$ & -4.1 & $71 / 59$ & -8.7 & -7.0 & $\mathrm{~N} 74^{\circ} \mathrm{E}$ & -5.8 & 1.51 \\
\hline Porphyrite & 2.5 & 20 & 358 & 285 & -8.9 & $260 / 44$ & -5.9 & $164 / 7$ & -3.0 & $67 / 45$ & -6.4 & -5.6 & $\mathrm{~N} 69^{\circ} \mathrm{W}$ & -6.0 & 1.07 \\
\hline Slate & 2.5 & 11 & 674 & 316 & -12.1 & $20 / 5$ & -7.9 & $286 / 46$ & -5.5 & $116 / 44$ & -12.1 & -6.7 & $\mathrm{~N} 22^{\circ} \mathrm{E}$ & -6.9 & 1.76 \\
\hline
\end{tabular}




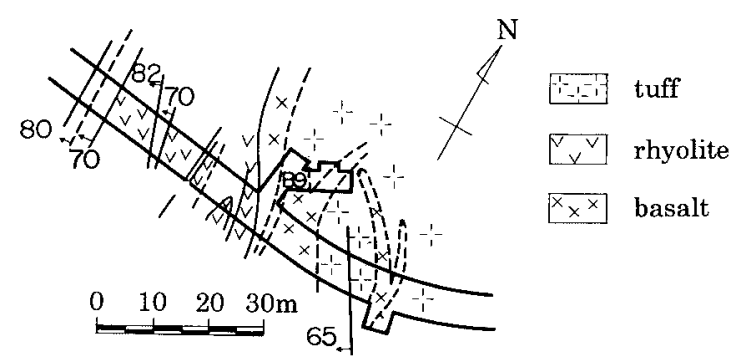

図 6 初期地圧測定位置 ( 青函トンネル調查坑)

林他，1977)。縦軸には測定個数を, 横軸には地圧の大きさを示し, さらに測定した位置の岩盤の堅さで分類している。計測にはオー バーコアリングによる応力解放法と AE 法を用いている。計測場 所は図 6 の B9 坑であり, ごく狭い範囲である。結果は若干ばら ついているが, 硬岩での計測結果の方が軟岩に比べて, 地圧が大 きい傾向であることが分かる。したがって,

(4)地圧は硬い岩盤で大きく軟らかい岩盤では小さく, 局在する。 ということができる。

地圧測定は経費と時間が掛かり, 同一地点で位置を変えて計測 することが少ないが, 特に日本においては激しい地款変動のため

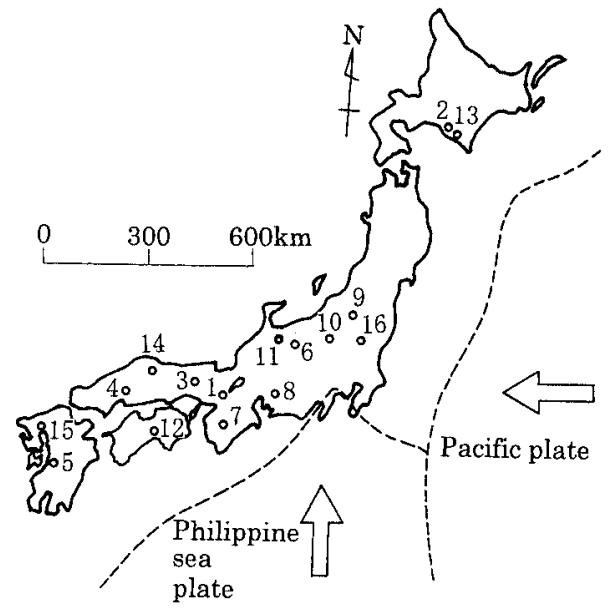

図 7 地下発電所空洞の所在位置
に地質が複雑となっており, 地圧の評価に際して注意すべき事項 と思われる。

\section{4. 大規模空洞掘削時の岩盤挙動}

空洞掘削時に各種計測を実施した地点の諸元を表 4 に, 図 7 に その位置を示寸 (日比野・本島, 1993)。岩盤の力学的条件として は電中研式岩盤分類で $\mathrm{B} \sim \mathrm{CM}$ 級, 弾性係数では $10 \sim 30$ 万 $\mathrm{kgf} /$ $\mathrm{cm}^{2}$, 剪断強度では $10 \sim 30 \mathrm{kgf} / \mathrm{cm}^{2}$ 程度, 被りの深さは $100 \sim$

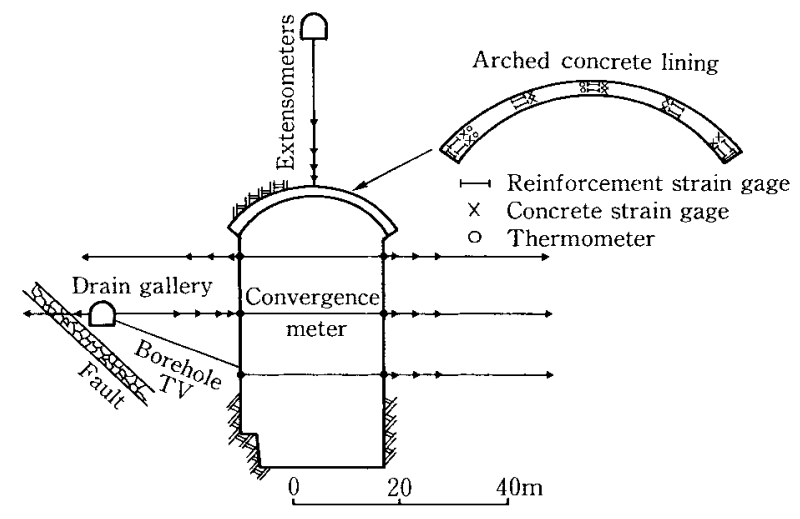

図 8 各種計測計器の配置

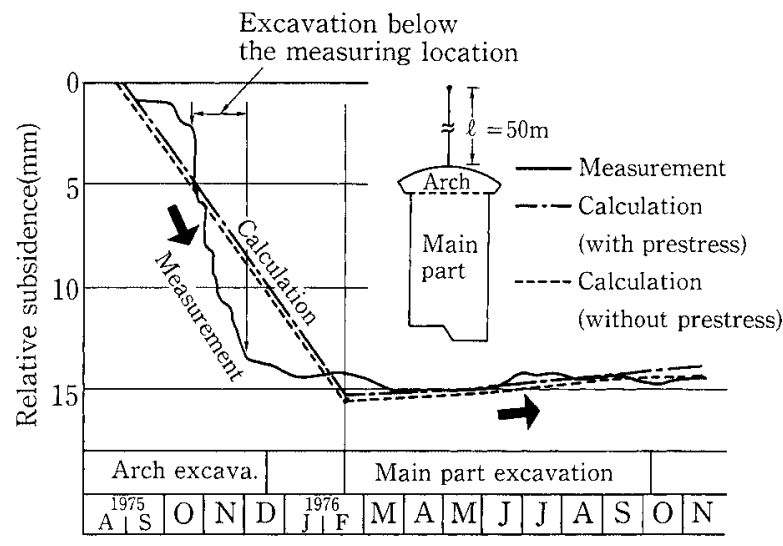

図 9 アーチ上部岩盤の掘削に伴う沈下量の変化 (サイト 7)

表 4 地下発電所空洞の諸元と岩盤条件

\begin{tabular}{|c|c|c|c|c|c|c|c|c|c|c|c|c|c|c|c|}
\hline \multirow{2}{*}{ Site } & & \multirow{2}{*}{ Kind of rock mass } & \multicolumn{3}{|c|}{ Size of cavern(m) } & \multicolumn{3}{|c|}{ Size of arched lining } & \multicolumn{3}{|c|}{ Ground pressure $(\mathrm{MPa})$} & \multirow[b]{2}{*}{$h(\mathrm{~m})^{91}$} & \multicolumn{3}{|c|}{ Properties of rock mass ${ }^{2}$} \\
\hline & & & Height & Width & Length & $t_{a}(\mathrm{~m})$ & $t_{c}(\mathrm{~m})$ & $R / S$ & $\sigma_{h}$ & $\sigma_{\mathrm{v}}$ & $\tau$ & & $E_{o}(\mathrm{GPa})$ & $\tau_{0}(\mathrm{MPa})$ & $\alpha$ \\
\hline 1 Kisenyama & (1968) & Shale, sandistone, chert & 51.0 & 25.6 & 60.4 & 2.04 & 1.20 & 0.236 & 1.3 & 3.9 & - & 250 & $6 \sim 12$ & $1.5 \sim 2.9$ & 0.16 \\
\hline 2 Niikappu & (1972) & Schalstein & 43.8 & 19.8 & 50.8 & 2.30 & 1.20 & 0.250 & 3.3 & 4.4 & 0.7 & 110 & 24 & 2.4 & 0.16 \\
\hline 3 Okutataragi & (1972) & Rhyolite, diabase & 49.2 & 24.9 & 133.4 & 1.88 & 1.00 & 0.243 & 5.8 & 6.5 & - & 240 & $35 \sim 10$ & $3.9-4.9$ & 0.05 \\
\hline 4 Oohira & (1973) & Sandstone, slate & 45.4 & 22.0 & 82.8 & 2.11 & 1.20 & 0.247 & 5.7 & 7.8 & 1.6 & 280 & $10-29$ & $1.0-2.5$ & 0.17 \\
\hline 5 Nabara & (1974) & Granite & 47.7 & 25.0 & 85.6 & 1.72 & 1.20 & 0.239 & 7.2 & 6.3 & 1.1 & 180 & $3-9$ & $0.5 \sim 1.5$ & 0.2 \\
\hline 6 Shintakase & (1975) & Granodiorite, diorite & 54.5 & 27.0 & 165 & 2.51 & 1.50 & 0.251 & 2.0 & 5.9 & 2.2 & 250 & $14 / 7^{4\rangle}$ & $3.1 / 1.3^{41}$ & 1 \\
\hline 7 Okuyoshino & (1976) & Shale, sandstone & 41.6 & 20.1 & 157.8 & 1.64 & 0.80 & 0.209 & 6.6 & 6.9 & 2.3 & 180 & $13 / 6$ & $2.0 / 0.8$ & 0.3 \\
\hline 8 Okuyahagi & (1978) & Granite & 47.8 & 22.4 & 103.3 & 2.00 & 1.00 & 0.251 & 7.4 & 10.8 & 1.0 & 340 & $15 / 7$ & $2.9 / 1.2$ & 0.8 \\
\hline 9 Numazawa & No.2 (1979) & Rhyolite & 47.6 & 26.0 & 96.5 & 2.05 & 1.10 & 0.242 & 4.5 & 3.4 & 0.8 & 160 & 10 & 1.4 & 0.1 \\
\hline 10 Tanbara & (1979) & Conglomerate & 49.5 & 26.6 & 116.3 & 2.49 & 1.50 & 0.248 & 4.5 & 7.0 & 1.9 & 240 & $16-20$ & $2.4-2.9$ & 0.4 \\
\hline 11 Arimine & $(1979)$ & Granite & 20.8 & 14.6 & 30 & 0.20 & 0.20 & - & 1,3 & 1.9 & - & 63 & $4 / 2$ & $1.7 / 1.3$ & 0.4 \\
\hline 12 Honkawa & $(1980)$ & Black schist & 47.4 & 26.3 & 98 & 2.01 & 1.00 & 0.225 & 5.4 & 7.1 & 0.9 & 270 & $12 / 8$ & $2.5 / 1.3$ & 0.7 \\
\hline 13 Takami & (1981) & Schalstein & 43.3 & 21.5 & 55 & 1.20 & 1.20 & 0.250 & 7.1 & 5.9 & 0.2 & 220 & $3-8$ & 0.14 & 0.8 \\
\hline 14 Matano & (1981) & Granite, porphyrite & 46.2 & 23.5 & 155.5 & 1.00 & 1.00 & 0.237 & 18.5 & 12.5 & 6.6 & 350 & $15 \sim 20$ & 2.9 & 0.5 \\
\hline 15 Tenzan & (1982) & Granodiorite & 48.0 & 24.0 & 89.0 & 1.767 & 1.00 & 0.26 & 15.0 & 11.0 & 1.2 & 500 & 25 & 7.4 & 0.5 \\
\hline 16 Imaichi & (1982) & Sandstone, breccia & 51.0 & 33.5 & 160.0 & 0.320 & 0.320 & - & 7.6 & 9.1 & 0 & 400 & 18 & 1.9 & 0.4 \\
\hline
\end{tabular}

1) $t_{c}$ : Thickness of abutment, $t_{c}$ : Thickness of crown, $R / S:$ Raise/Span 2 2) $E_{0}:$ Deformability, $\tau_{0}:$ Cohesive strength,

$\alpha$ : Creep coefficient 3) Depth of overburden 4) Anisotropy 
$500 \mathrm{~m}$ である。表に示した地点では, 空洞掘削に先んじて, 空洞 掘削解析を行い掘削時の岩盤挙動の予測をして空洞設計を行い, 掘削時には各種計測を行った。計測器配置の一例を図 8 に示す。 計器の種類としては, 岩盤変位計, コンクリートのひずみ計, 鉄 筋計, 温度計, PS ストランドの荷重計等がある。図 9 にはアーチ 上部岩盤の掘削に伴う沈下量の計測結果の一例を示す。

表 4 に示した 16 地点での各種計測結果より抽出された岩盤の挙 動特性を以下に示寸。

\section{4 - 1 岩盤の変形と不連続面との関係}

空洞掘削時のボアホール壁面の状況を, ボアホールテレビ BTV ( 分解能は $0.25 \mathrm{~mm}$, 図 10) で観察した結果 (サイト 6 : 花崗閃緑 岩)について述べる (堀・宮腰, 1977)。図 11 にはその観察用ボア ホール ( 平行して 2 本掘削) の位置と空洞との関係を示す。空洞 掘削の進行に応じて数回観察が実施された。掘削終了時点での掘 削による岩盤中の節理開口量を表 5 に示す。開口量は 2 孔でそれ ぞれ $27 \mathrm{~mm}$ と $21 \mathrm{~mm}$, 平均で $24 \mathrm{~mm}$ である。ボアホールの観測 した長さは $22 \mathrm{~m}$ であるので, 平均で $1 \mathrm{~m}$ 当たり約 $1 \mathrm{~mm}$ の開口 量となる。表中で開口節理は空洞掘削前に孔壁に存在が確認され た節理であり, マイクロ節理は掘削前には BTVの分解能以下で存 在が確認できなかった節理である。表 5 の結果より（1）掘削によ り岩盤は弾性的なひずみ変化による連続的なひずみ変位以外に, 節理の開口による不連続な変位 ( 開口変位と呼ぶ ) を生じている ことが分かる。つまり，「掘削により岩盤の応力が変化し，岩盤は ひずみの変化による連続的な変位を生ずるが，さらに節理等が開 口して不連続な変位が発生している」ことになる。(2) 開口変位は 既存の節理が開口することにより生ずるだけでなく，新しく節理

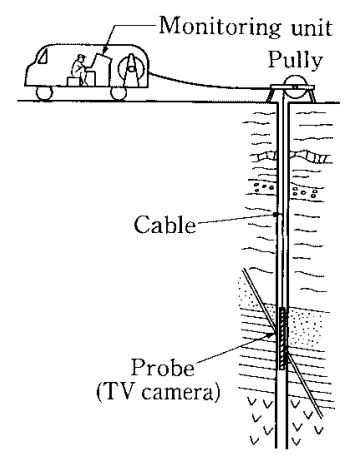

図 10 ボアホールテレビ (BTV) の概念図

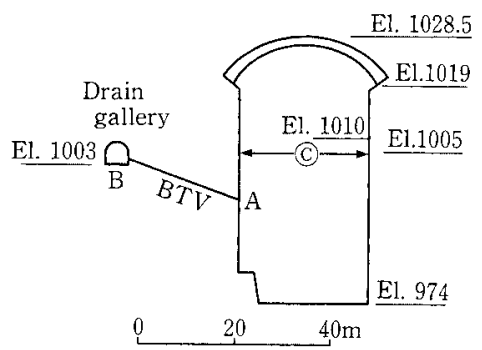

図 11 ボアホールテレビ観察孔と内空変位計測の配置 (サイト 6)

表 5 掘削による節理の開口量 (サイト 6 ; 堀ほか, 1977)

\begin{tabular}{lcccc}
\hline & \multicolumn{2}{c}{ Hole No. 1 } & \multicolumn{2}{c}{ Hole No. 2 } \\
\cline { 2 - 5 } & Accumulated & Ratio & Accumulated & Ratio \\
& aperture (mm) & $(\%)$ & aperture (mm) & $(\%)$ \\
\hline Open joint & 7.63 & 28.2 & 2.50 & 12.0 \\
Micro joint ${ }^{1)}$ & 19.37 & 71.8 & 18.37 & 88.0 \\
Total & 27.00 & 100.0 & 20.87 & 100.0 \\
\hline
\end{tabular}

1) Joint with an aperture of less than $0.25 \mathrm{~mm}$ at the initial stage
表 6 岩盤の種類と開口変位率 $k$ との関係

\begin{tabular}{clccc}
\hline Site & $\begin{array}{c}\text { Kind of } \\
\text { rock mass }\end{array}$ & $\begin{array}{c}\text { Total } \\
\text { displacement }\end{array}$ & $\begin{array}{c}\text { Opening } \\
\text { displacement }\end{array}$ & $\begin{array}{c}\text { Ratio } \\
k\end{array}$ \\
\hline 6 & Granodiorite, diorite & $37 \mathrm{~mm}$ & $24 \mathrm{~mm}$ & $65 \%$ \\
7 & Shale, sandstone & $20 \mathrm{~mm}$ & $4.5 \mathrm{~mm}$ & $23 \%$ \\
\hline
\end{tabular}

ができて開口して生ずることが分かる。

岩盤変形量については別途岩盤変位計やコンバージェンスによ る計測が行われている。そこで BTV 計測の標高に近いコンバー ジェンス (図 11 の測線65) ) の值を調べてみると $74 \mathrm{~mm}$ であった。 したがって, 岩盤変位の $37 \mathrm{~mm}(74 / 2)$ のうち $24 \mathrm{~mm}$ 程度は節理 が開口寸ることにより生じていることになる。残りの $13 \mathrm{~mm}$ は岩 盤のひずみ変化による連続的な変位によると考えられる(日比野, 本島，1994)。したがって，

(5)岩盤の変形はひずみ変位と開口変位からなる，つまり

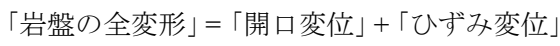

と考えられる。

いま一つ重要なことは岩盤の全変形に占める開口変位の比率で ある。その比率を開口変位率 $k$ と定義すると, 上記の例では $k=24$ $/ 37=65 \%$ となり, 開口変位の方がひずみ変位よりも大きいこと が分かる。この比率は岩盤の種類により異なることが考えられる。 そこで, 表 6 には頁岩や砂岩からなる地点での空洞掘削時の同様な 計測結果と上記の結果を併記して示した (日比野・本島, 1994)。こ の場合の比率は $k=23 \%$ と小さな值になっている。したがって, 節理の発達しやすい火成岩系の岩盤では開口変位率が大きく, 堆 積岩系の岩盤では小さい可能性が有る。つまり,

(6)火成岩系の節理性岩盤の方が堆積岩系の非節理性岩盤よりも 開口変位率 $k$ が大きい。 このことはもつと多くの計測結果を集め結論を出す必要が有る が, 後述する図 15 の結果からも推測され次節 $4 \cdot 2$ で論議する。

\section{$4 \cdot 2$ アーチコンクリートライニングの応カの発生原因}

地下構造物に外力がどのように作用するかについて考察する。 図 8 には地下発電所空洞のアーチコンクリートライニングの鉄筋 計やひずみ計の埋設位置を示した。図 12 にはそれら鉄筋計応力の 掘削に伴う変化を示す。コンクリートの打設直後コンクリートの 温度上昇により応力が急増するが, 約 1 か月後には温度の低下に 伴い減少する。その後空洞本体 ( 図中の插画(1)～(5)の部分 ) の掘 削に伴いライニング内に応力が発生するのが分かる。掘削が終了 すると鉄筋応力も収束している。この鉄筋応力からコンクリート 応力を算定し, アーチコンクリートの上縁面と下縁面での各計器 の掘削終了時の平均值分布を示したのが図 13 である。図中の○の 番号は表 4 の地点名を示す。地点ごとに応力は異なり, $20 \sim 100$ $\mathrm{kgf} / \mathrm{cm}^{2}$ となっている。分布の形はアーチクラウンで大きくアーチ アバッツメントで小さい傾向がある。これらの応力をさらに地点ご とに平均した值とアーチ直下の空洞本体の内空変位 $W($ コンバー ジェンス) と比較したのが図 14 である (日比野・本島, 1993)。若 干のばらつきがあるがほぼ直線関係にあり, 内空変位とライニン グ応力は比例することを示している。このことは

(7)岩盤内構造物 (アーチコンクリートなど) 一の荷重は岩盤の変

形によって生ずる。

ことを意味している。アーチコンクリートを打設したときには温 度応力を除けばアーチコンクリートは応力がゼロである。その後 空洞本体掘削時に掘削相当外力 ( 掘削予定面を自由面にするのに 必要な最小限の外力: 林・日比野, 1968) が作用して空洞側壁が空 洞の内側へ変位し, その為にアーチコンクリートが水平方向に圧 縮されて, その結果アーチコンクリートに応力が生ずる。したがっ 


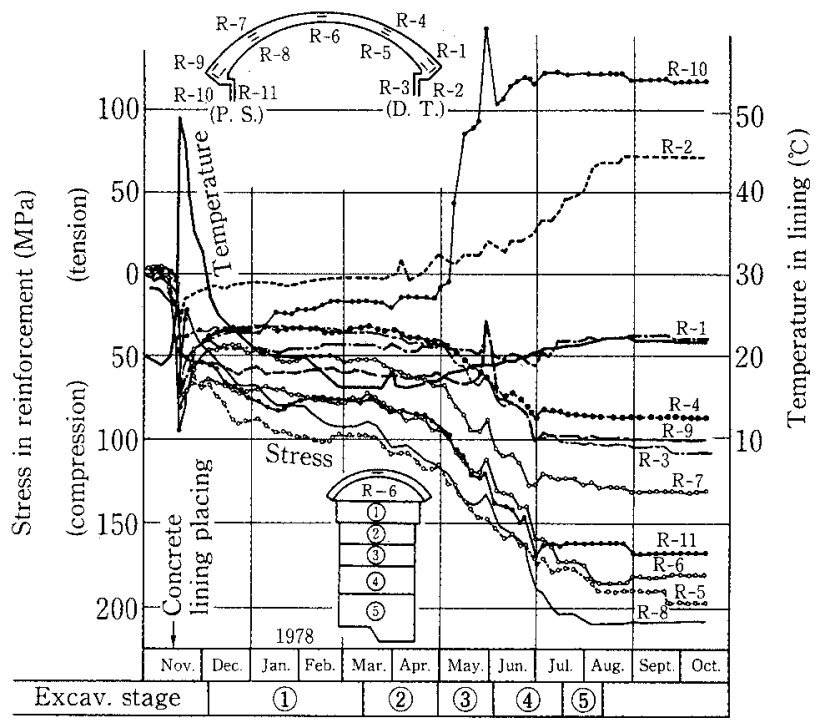

図 12 アーチコンクリートライニングの鉄筋応力の 掘削による変化 (サイト 8 )

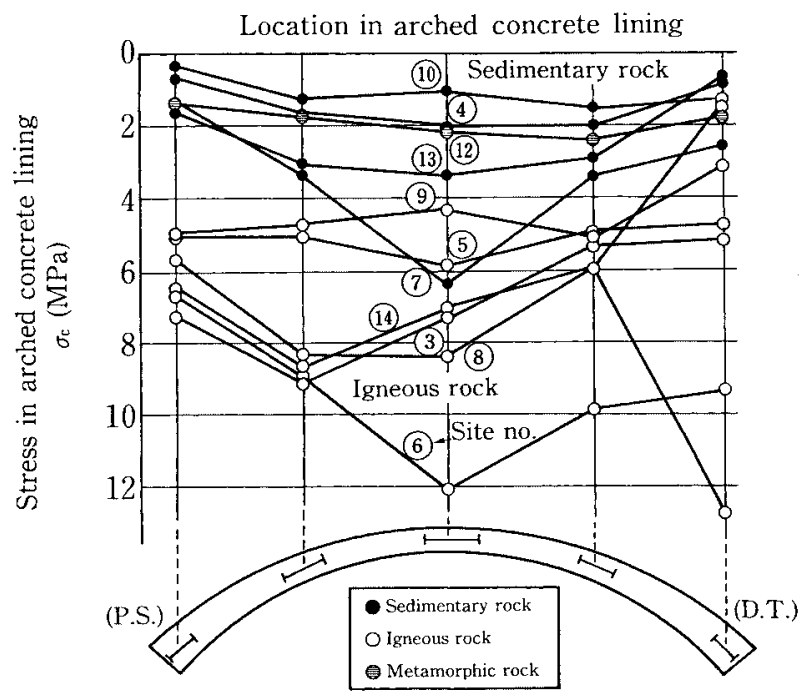

図 13 アーチコンクリートライニングの掘削終了時の応力分布

て「岩盤構造物の設計に際しては, 周辺岩盤の変形量を基準にし て設計することが必要」である。

ついで図 14 の結果を, 空洞の奥行き長さ $L$ との関係で整理し直 してみると図 15 を得る。この結果から (1) 空洞の規模 (長さ $L$ ) が 大きくなるとアーチコンクリートの応力が大きくなる傾向がみら れる。さらに(2) 火成岩系の岩盤では堆積岩系の岩盤に比べ, アー チコンクリートの応力の值が 2 ～ 3 倍大きいことが分かる。した がって,

(8)火成岩系の節理性岩盤の方が堆積岩系の非節理性岩盤に比べ 掘削による変形量が大きい。

ことが分かる。

つぎに，通常のトンネルの場合には切羽から直径程度離れれば トンネルを 2 次元として扱いうるといわれている。この考えでゆ くと上記 (1) に関しては, 空洞の断面は $(20 \sim 30 \mathrm{~m}) \times 50 \mathrm{~m}$ である ので, 空洞の長さが約 $100 \mathrm{~m}$ を超せば応力は一定值になってもよ いことになる。しかし $100 \mathrm{~m}$ を超しても応力は単調に増加し収束 していない。特に火成岩系の岩盤の場合にこの傾向が強い。もち ろん地点ごとに地圧や弾性係数も異なり, 同じ土俵で論ずるのは 無理かもしれない。しかし別途地圧や弾性係数による影響を調べ

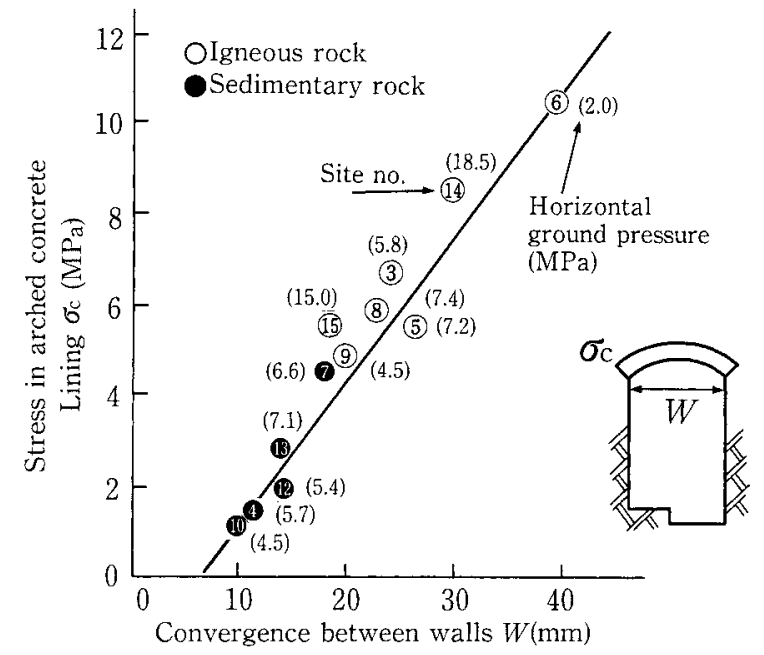

図 14 アーチコンクリートライニングの応力と内空変位 $W$ との関係

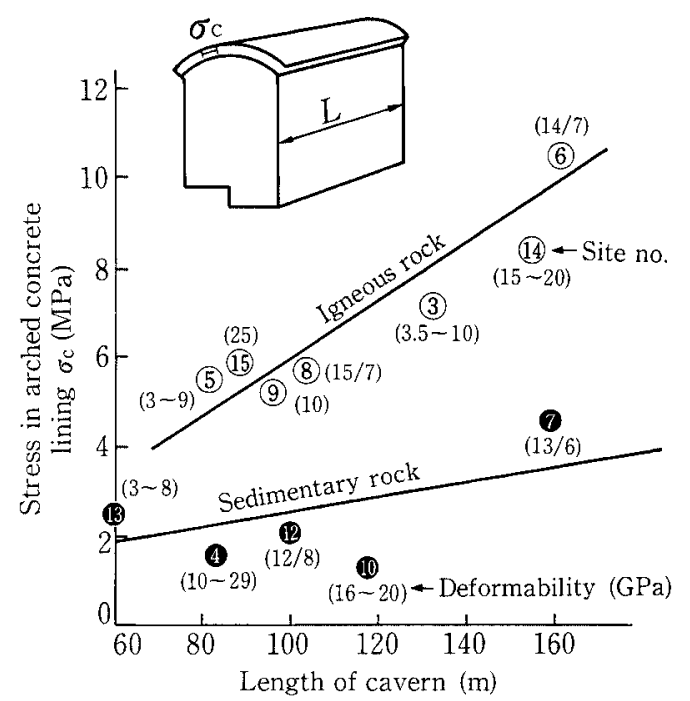

図 15 アーチコンクリートライニングの応力と空洞の長さ $L$ との関係

てみたが傾向はみられなかった（ちなみに図中には各地点の弾性 係数の值を示したが定かな傾向はみられない)。このことより，地 下発電所のようにスケールの大きい空洞では解放される自由面が 大きいので，節理等の開口の影響がより顕著となり，不連続岩盤 としての特性が現れるために, 空洞の奥行が長くなっても 2 次元 的な扱いはできないことを意味していると思われる。

（2）については，前節 $4 \cdot 1$ の6)で述べた開口変位率 $k$ は岩盤の 種類によることに関係していると思われる。つまり炡成岩系の岩 盤では堆積岩系の岩盤に比べて, 開口変位率がより大きく, した がって岩盤変形が大きくなり, その結果ライニング応力が 2 倍か ら 3 倍になったと考えられる。さらに, 空洞の長さが $60 \mathrm{~m}$ から $160 \mathrm{~m}$ 一と大きくなるにつれて, 両者の比率は 2 倍から 3 倍へと 増大寸る傾向を示している。この例からだけで判断するのは妥当 ではないかもしれないが，「開口変位率 $k$ は空洞の規模が大きくな ると増大寸る可能性がある」ことを意味している。概念的には図 16 に示すように, 空洞のスケールが大きくなり解放面が大きくな ると節理等はより開口しやすくなり， $k$ が増大寸ることによると 考えられる。

図 15 における地点の岩盤の種類を整理すると, 火成岩系の岩盤 としては, 花崗岩, 花崗閃緑岩, 流紋岩, 輝緑岩などがあり, 堆 積岩系としては砂岩, 頁岩, 粘板岩, 礫岩, 輝緑凝灰岩などとなっ 

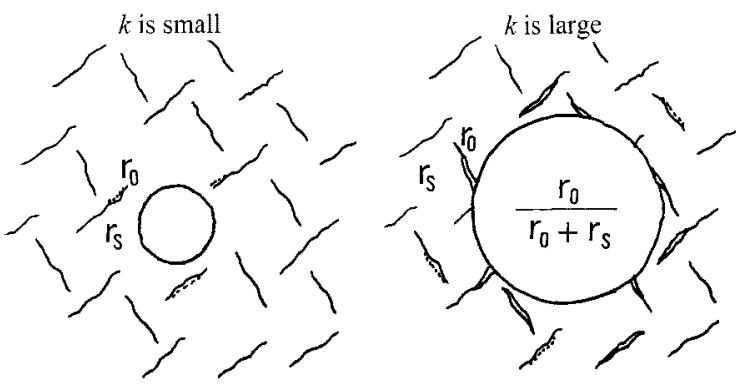

図 16 開口変位率 $k$ と空洞サイズとの関係

ている。

上記のことを考えると，巨大な空洞を建設するとき岩盤試験に よる弾性係数や強度が同じならば, 火成岩系の岩盤よりも堆積岩 系の岩盤に建設する方が空洞の変形もより少なく, より安定な岩 盤構造物が作れると思われる。

\section{$4 \cdot 3$ 解放面の大きさとゆるみ領域の関係}

アーチ上部岩盤 ( 地圧解放の自由面の幅は約 $25 \mathrm{~m}$ ) と空洞側壁 (自由面の幅は約 $50 \mathrm{~m}$ で, アーチ上部岩盤に比べ 2 倍の広さ)を 比べると, 岩盤変形 ( 緩み領域) の発生に特徵的な違いがあるよ うに思われる。

図 17 にはアーチ上部岩盤内の沈下量の分布を示す (日比野・本 島, 1993)。壁面から数 $\mathrm{m}$ の範囲で大半の沈下は生じ, さらに深部 では沈下がほとんど生じていないことが分かる。沈下量の変化を 距離で除して見かけのひずみにしたのが図 18 である。緩みの概念 の定義は難しいが，「掘削時の応力集中により岩盤の強度や固結度 が低下した領域で, 岩盤構造物を建造するためには補強を要する 領域」をゆるみ領域と呼ぶことにする。アーチ上部の緩み領域は $5 \sim 8 \mathrm{~m}$ で, 見かけのひずみの值では $10^{-3}(0.1 \%)$ 程度以上の領域 がゆるみ領域となっていると考えられる。つぎに, 側壁岩盤でこ の見かけのひずみ分布をみると, 図 19 に示すようにゆるみ領域は 地点ごとに様々で, 地点によっては $20 \mathrm{~m}$ にも達していることが

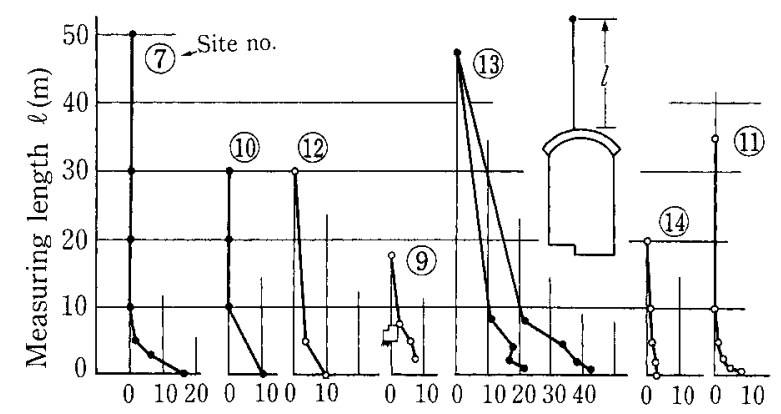
Relative subsidence of ceiling $\operatorname{rock}(\mathrm{mm})$

図 17 アーチ上部岩盤の掘削終了時の沈下量分布

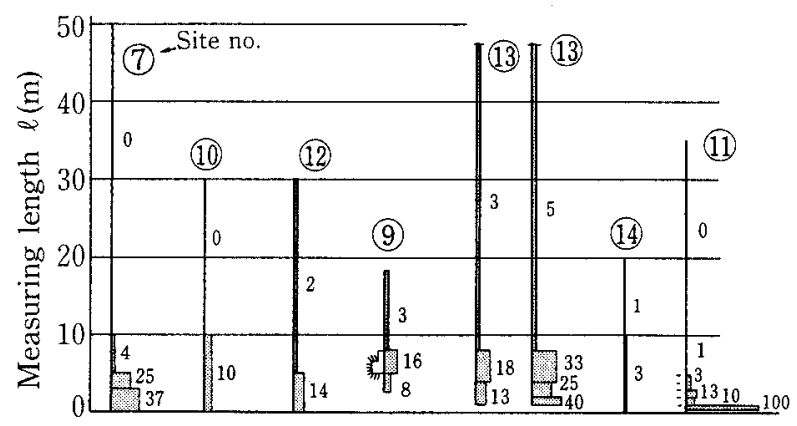

Apparent strain of ceiling rock $\left(10^{-4}\right)$

図 18 アーチ上部岩盤の見かけひずみの分布
(Penstock side) (Site no.) (Draft tube side)

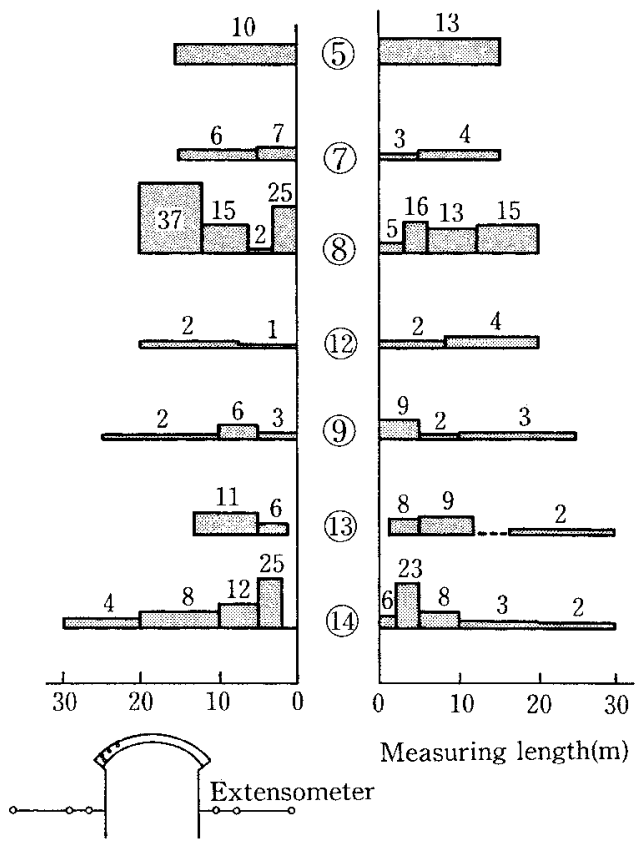

図 19 空洞側壁岩盤の見かけひずみ $\left(10^{-4}\right)$ の分布

分かる。地圧成分の大きさで夕れば, 表 3 に示したように水平成 分は鉛直成分の約 1.4 倍で, 地圧成分の大きさから考えれば, 側 壁のゆる夕領域の深さはアーチ部の 1.4 倍程度の $7 \sim 12 \mathrm{~m}$ 程度と 考えられる。アーチ部分は掘削後アーチライニングを打設してお り, その効果が考えられるが, 側壁は PS ストランドにより補強さ れており, 条件としてはアーチ部分と大差はないと考えられる。 したがって, 残る条件の一つとして, 掘削による自由面の幅が側 壁では約 $50 \mathrm{~m}$ とアーチ部分に比べて 2 倍と大きい。したがって, 解放面の大きさのスケール効果により節理等の開口がアーチ部岩 盤に比べ側壁ではより顕著となり, ゆるみ領域の増大につながっ たと考えられる。このことから，

(9)緩み領域の深さは, 地圧解放面の面積の大きさに比例する以 上に深くなる。

と考えられる。

\section{5. 地下空間利用への展望}

エネルギー関連の地下利用は，これまで述べてきた地下発電所 以外に, 高レベル放射性廃棄物の地下処分, 圧縮空気エネルギー 貯蔵発電, 石油備蓄, LNG 地下貯蔵などがあり, 交通輸送関係で は第二東名・名神高速道路などがある。また, 生活関連では大深 度地下法案が成立し, 地上と地下を一体化しての都市の地下活用 機運が生じてきた。ここでは紙面の関係上, 都市地下利用に関し 若干の考えを述べる。

\section{$5 \cdot 1$ 地下空間の価値と便益}

地下空間の利用価值と便益は, 社会システムのあり方および地 下特性の和と, 工学レベルとの積で表わすことができるといわれ ている。つまり,

\begin{tabular}{|c|c|c|c|}
\hline $\begin{array}{c}\text { 地下空間の } \\
\text { 利用洒值と便益 }\end{array}$ & $=$ & & \\
\hline $\begin{array}{c}\text { 社会システム } \\
\text { のあり方 }\end{array}$ & + 地下特性 & $x$ & $\begin{array}{l}\text { 利用技術と } \\
\text { 工学レベル }\end{array}$ \\
\hline
\end{tabular}

この式で考えると地下空間の利用価值と便益は, 従来に比べて近 年その価值が大きく変化していることを認識する必要がある。つ 


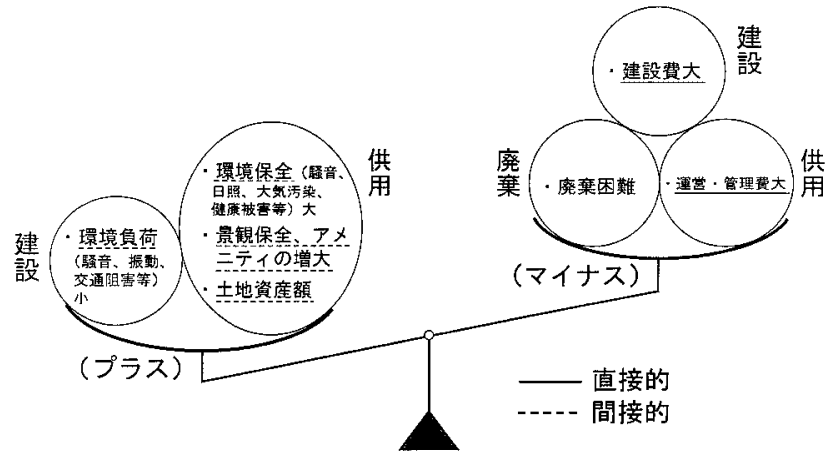

図 20 地下空間利用の価値と便益のトータル評価

まり，地下特性は耐震性・隔離性・遮断性・耐候性など従来と同 じであるが，工学レベルは近年の岩盤力学や土質力学の進歩によ り, 岩盤では地下 500 数千 $\mathrm{m}$, 土質地盤では地下 $50 \sim 100 \mathrm{~m}$ 深 部での工学的利用が可能になってきている。さらにここで注目す べきは, 大きな変化が近年の社会システムのあり方にみることが できる。つまり, 現代の社会においては騒音, 健康問題, 電磁波 障害，ゴミ処理問題等に見られるように，「環境問題」が重要な キーポイントとなってきている。この点地下空間は隔離性・遮断 性などの特質を有し, 環境保全に優れているとともに景観保全な ぞ都市のアメニティ創造に優れている。これらの特性を十二分に活 用していくことにより, 地下空間の利用価值や便益はこれまでに比 べて大きく増大し, 今後大きな発展が期待される。ただ一つ, 環境 問題や景観などはその価值を数量的に表現するのが必ずしも容易 ではないが，以下に示すようにその方面の研究も進んできている。

一例として, 道路建設における地上と地下の比較を考えてみる ( 京谷・丸山他, 1994)。地下に道路を建設すると, 排気ガスの集 中管理による除去や騒音対策などが有利となり, 地価の低下も防 げるが建設費は増大する。一方, 地上に道路を建設すると排気ガ スの為に周辺住民一の健康面での懸念があり, 地価の低下が生じ たりする。この場合, 従来だと直接的な建設費の比較中心で論議 が行われていたが, 最近では, ヘドニックアプローチなど (松尾・ 林, 1998)により間接的な効果も考慮してこれら社会環境影響評価 ができるようになってきた。

図 20 に示すように, 建設費や管理費の増大, 廃棄困難など短期 的・直接的な観点がこれまで中心であったが，今後はさらに環境 負荷の軽減, 環境保全・景観保全, アメニティの増大などの評価 も加えて「社会システム全体として長期的・間接的な効果を考え ていく必要」がある。

\section{$5 \cdot 2$ 大深度地下法案}

大深度地下の公共的使用に関する特別措置法が平成 12 年 5 月に 成立した。それに関寸る政令および施行令が 11 月に内定し, 平成 13(2001) 年 4 月に施行されることになった。適用対象は東京・大 阪・名古屋を中心とする三大都市圈の政策区域である。大深度の 定義は図 21 に示寸ように地下約 $40 \mathrm{~m}$ 以下であり, 従来は利用が 困難であった私有地の地下を公共的な目的に使用できる道が開か れた。

平成 12 年 12 月 15 日の日刊建設工業新聞には, 地下空間を利用 した大都市新生プロジェクト構想として, 高速道路や高速鉄道の 地下化, 地下ごみ処理システム, 地下物流拠点の整備など 25 件の 構想が日本プロジェクト産業協議会で纏められたと報じている。 今後も各種提案がなされ都市計画に組み込まれたり, 実施の検討 が行われたりしていくものと思われるが，ここで今一度地下利用 の理念について述べてみたい。

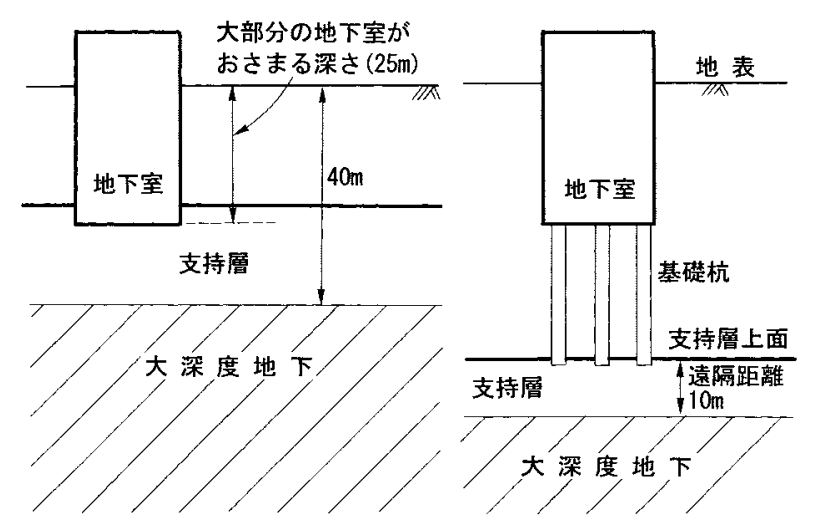

図 21 大深度地下の定義 (国土庁ホームページ，一部省略)

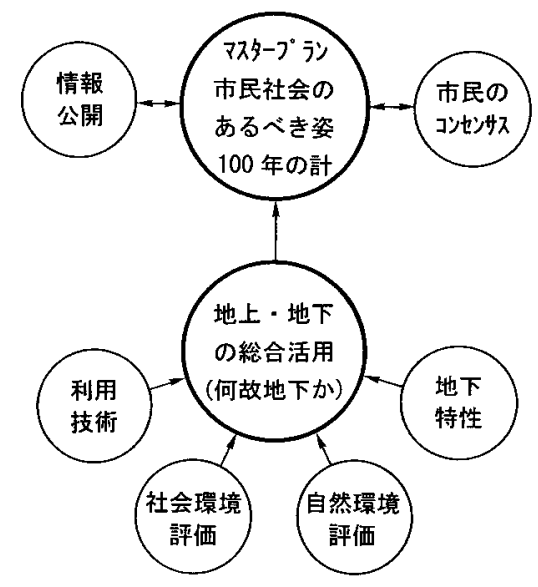

図 22 地下利用の基本

都市の基本はいうまでもなく，1）市民の安全でしかも安心でき るアメニティのある都市の創造であり, その目的達成のために, 2) 地上と地下を総合的に活用することが肝要である。OECD 勧告 (1970 年) の「21 世紀の都市は, 地上の使用を住宅・公園・広場 に限定し, 運輸, 交通, 通信, 電力, 水道, ガスなどの施設はも とより, 駐車場, 車庫, 塵芥, 下水などの施設もすべて地下に収 容することを理想とする」を今一度想起する必要がある。そして, その実現のためには, 下記の四つの事項が重要と考えられる。

第一に, どのような都市 (地上十地下) を建設するかという都 市の理想像ともいうべきマスタープランが基本である(図 22)。100 〜 200 年先までを見通した青写真である。第二に，そのプランは 市民の参加とコンセンサスのもとに十分な情報公開のもとに作成 されることが必要である。第三には，地下利用の計画に際し $5 \cdot 1$ で述べたように，自然環境はもちろんのこと社会環境影響評価を 行い, 何故地下なのかを, 経済性を含めて 100 年などの長期スパ ンのもとに間接的な効果を十分に評価して作成する。第四には, 市民と行政や自治体が一体となって実行する。この 4 つのプロセ スを経ることにより初めて健全な地下利用が可能になると思われ る。昭和 60 年代に盛んに地下利用が論議された。しかしバブル崩 壊とともにそれらは消えてしまった。たしかに経済的な面は重要 であるが，消えた理由はやはりそれ以上に，都市としての長期的 なマスタープランに基づいていなかったなど 4 つのプロセスを経 ていなかったからではないだろうか。

戦後の日本経済の復興は世界の中でもめざましく, GNP の飛躍 的な発展など目をみはるものがあった。しかしあまりにも経済的 な発展を急ぎすぎ，他の多くのことを切り捨てて来たように思わ れる。戦後半世紀以上経った現在，100〜200 年後の日本をどの 
ような姿にもっていくのか, 地上と地下を総合活用した都市のあ るべき姿を,ここらでゆっくり考える必要がある。

\section{6. まと め}

空洞スケールが大きくなると, 節理等の岩盤不連続面による岩 盤挙動への影響がより顕著となる。本論では, 断面積が約 1,000 $\mathrm{m}^{2}$ の地下発電所空洞掘削時の計測結果を中心に検討して, 岩盤の 特性, 掘削時の岩盤挙動特性として以下の結論を示した。

(1)平板載荷試験の弾性係数は過小評価である。

(2)節理の卓越度が約 $10 \%$ を超すと異方性が現れる。

(3)日本では地圧の水平成分が鉛直成分よりも卓越寸る。

(4)地圧は岩盤の硬軟により局在する。

(5)岩盤の変形は「ひずみ変位」と「開口変位」からなる。

(6)節理性岩盤の方が非節理性岩盤よりも変形が大きい。

(7)開口変位率は岩盤の種類と空洞のスケールにより異なる。

(8)構造物への荷重は岩盤の変形によって生ずる。

(9)緩み領域の深さは，地圧解放面の面積の大きさに比例する以 上に深くなる。

ただし，計測事例の数が少なく仮説と考えるべきものもある。仮
説的であっても岩盤構造物の挙動を考えるうえで有効であると考 え結論として示した。今後新しい成果が出て上記の結論が修正さ れれば，それは学問の進歩であって喜ぶべきことと思われる。

ついで, 地下空間利用の将来展望として，1）近年の環境問題に 対する関心の高まりなどが，地下空間の利用価值と便益を従来に もまして増大させている，2) 従来は直接的・短期的評価が中心で あったが，間接的・長期的評価も取り入れて，トータルとして評 価すること，3）地下利用の 4 つの基本プロセスに基づくこと，が 重要であることを示した。

\section{引用文 献}

林 正夫 ·日比野敏 (1968) : 電力中央研究所報告 No. 67095 日比野敏・林 正夫・本島 睦 (1980) : 電力中央研究所報告 No.379028

日比野敏・本島 睦 (1993)：土木学会論文集, No. 481/ III -25, p.125-134

日比野敏・本島 睦 (1994) : 第 9 回岩の力学国内シンポジウム講演論文集, p.689-694 Hibino, S. and Kamijo, M.(1998) : Proc.3rd North American Rock Mechanics Symp. CDrom, Cancun

Hibino, S. and Motojima, M.(1999) : Proc. 9th Cong.Int.Soc.Rock Mech. p. 385-388, Paris 堀 義直・宮腰勝義 (1977) : 電力中央研究所報告 No. 377533

金川忠・林 正夫・仲佐博裕 (1977) : 土木学会論文集, No. 258, p. 63-75

Kanagawa, T., Hibino, S., Ishida, T., Hayashi, M. and Kitahara, Y.(1986) : Int. J. Rock Mech. Min. Sci. \& Geomech. Abstr. Vol. 23, No. 1, p. 29-39

京谷孝史・丸山世紀・林 良嗣 (1994)：地下空間シンポジウム, p. 125-133

松尾 稔・林 良嗣 (1998) : 都市の地下空間, 鹿島出版会, p. 42-47 